\title{
Prediksi Komposisi Unsur dan HHV Sampel Bahan Bakar Sampah Incinerator PLTSa UNSIKA Menggunakan Analisis Proksimat
}

\author{
Imam Firdaus ${ }^{1, a)}$ \\ ${ }^{1}$ Program Studi Teknik Mesin Universitas Singaperbangsa Karawang, \\ Jl. HS. Ronggo Waluyo, Paseurjaya, Kec. Teluk jambe Timur, Kabupaten Karawang, J7awa Barat 41361 \\ a)1610631150061@ student.unsika.ac.id (corresponding author)
}

\begin{abstract}
Abstrak
Pemanfaatan energi alternatif pada era modern ini sangat cepat perkembangannya, dimulai dari untuk kebutuhan sehari-hari hingga pemanfaatan di skala industri. Akan tetapi dalam proses perancangannya dibutuhkan data yang sangat banyak agar memperoleh hasil yang akurat. Salah satu di antaranya ialah nilai HHV dan komposisi unsur pada biomassa, yang dalam proses pengujian memerlukan waktu dan biaya yang cukup besar. Belum lama ini banyak penelitian tentang hubungan dari analisa proksimat dengan HHV maupun komposisi unsur tersebut, yang sangat bermanfaat dalam perancangan tungku atau pengoperasian yang menggunakan bahan bakar biomassa. Pada incinerator PLTSa di Universitas Singaperbangsa Karawang dibutuhkan komposisi unsur untuk menganalisis gas buang pembakarannya dan HHV untuk nilai kalor pembakarannya. Sampel yang diambil ada 3 buah sampel, yang terdiri atas campuran sampah kertas, daun mangga, daun pisang, dan daun ketapang, dengan unsur-unsurnya yang terdiri atas $\mathrm{C}$ (karbon), $\mathrm{H}$ (hidrogen), dan $\mathrm{O}$ (oksigen), dengan nilai masing-masing berkisar antara 32,87-33,43\%, 4,22-4,26\%, 26,05-26,47\%. Sedangkan nilai HHV berkisar antara $15689,83-15690,53 \mathrm{~kJ} / \mathrm{kg}$.
\end{abstract}

Kata kunci: analisis proksimat, incenerator, nilai kalor, sampah padat

\begin{abstract}
The utilization of alternative energy in the modern era is rapidly developed, ranging for daily needs to utilization in an industrial scale. However, the design process needs in order to obtain accurate results. One of them is the value of $H H V$ and the composition of elements in biomass, which requires considerable time and cost in the testing process. Recently, there were a lot of researches on the relationship of proximate analysis with HHV and also the composition of these elements, which is very useful in the design of furnaces or operations that use biomass fuels. In the incinerator of PLTSa at Singaperbangsa Karawang University elements composition is needed to analyze the exhaust gas combustion and HHV for the value of the calorific combustion. There are 3 samples taken, consisting of mixture of paper waste, mango leaves, banana leaves, and ketapang leaves, which consist of elements such as $C$ (carbon), $H$ (hydrogen), and $O$ (oxygen), with value ranges from 32.87-33.43\%, 4.22-4.26\%, 26.05-26.47\% respectively. While the HHV values range from $15689.83-15690.53 \mathrm{~kJ} / \mathrm{kg}$.
\end{abstract}

Keywords: calorific value, incinerator, proximate analysis, solid waste.

\section{PENDAHULUAN}

Sampah atau dalam istilah bahasa Inggris adalah waste mempunyai banyak definisi dalam ilmu pengetahuan. Pada intinya menerangkan bahwa suatu bahan yang berasal dari aktivitas manusia atau alam yang terbuang atau sengaja dibuang dan masih belum mempunya nilai atau manfaat. Sampah memiliki beberapa jenis di antaranya yaitu padat, gas, dan cair. Berdasarkan sifatnya sampah dapat dibagi menjadi dua, yaitu sampah organik atau sampah yang asalnya dari makhluk hidup yang bisa di daur ulang, dan sampah anorganik yang berasal dari bahan non-hayati yang tidak dapat di daur ulang [1], [2]. Incinerator merupakan suatu alat yang dimanfaatkan atau digunakan untuk melakukan proses pembakaran suatu sampah baik yang berbentuk cair, padat, dan gas. Fungsi dari alat ini ialah untuk mengubah ukuran sampah menjadi ukuran yang lebih kecil dari sebelumnya, hingga mencapai kurang lebih 50-90\% ukuran aslinya. Alat ini dibedakan menjadi dua jenis yaitu batch dan kontinu, yang dibedakan dalam pemasukan sampah ke dalam alatnya. Untuk jenis batch sampah dimasukkan hingga kapasitas maksimal dari alat tersebut kemudian melalui proses pembakaran hingga tersisa hasil pembakarannya yang diperoleh dalam satu waktu tertentu. Sedangkan untuk jenis kontinu untuk sampahnya dimasukkan secara terus-menerus selama proses pembakaran terjadi dalam waktu yang berkelanjutan [3].

Analisis proksimat merupakan analisa yang menunjukkan persentase total dari kadar air, kadar abu, fixed carbon, dan volatile matter dalam suatu bahan bakar padat. Komposisi unsur atau yang berasal dari analisa ultimat adalah analisa laboratorium suatu bahan bakar padat yang mengandung komposisi karbon (C), hidrogen $(\mathrm{H})$, oksigen $(\mathrm{O})$, nitrogen $(\mathrm{N})$, dan sulfur $(\mathrm{S})$ [4]. 
Dalam penelitiannya Parikh dkk. [5] hanya mempertimbangkan kandungan dari volatile matter dan fixed carbon dalam memprediksi $\mathrm{C}, \mathrm{H}$, dan $\mathrm{O}$ dengan kesalahan absolut rata-rata masing-masing 3,21\%, 4,79\%, dan 3,4\%. Sedangkan Shen dkk. [6] mengembangkan berdasarkan hubungan antara volatile matter, fixed carbon dan kadar abu dalam memprediksi unsur $\mathrm{C}, \mathrm{H}$, dan $\mathrm{O}$ dengan kesalahan absolut rata-ratanya masing-masing $3,17 \%$, 4,47\% dan 3,16\%. Dalam penerapannya bahan bakar padat memiliki basis hasil dalam menyatakan nilai dari suatu parameter dan menunjukkan nilai tersebut dalam suatu kondisi tertentu. Adapun basis yang sering digunakan sebagai berikut :
a. as recieved basis $(\mathrm{ar} / \mathrm{r})$
b. air dried basis (adb)
c. dry basis $(\mathrm{ad} / \mathrm{d})$
d. dry ash free (daf)

Komposisi yang ada pada setiap basis diklasifikasikan seperti yang ditunjukkan pada gambar 1 .

\begin{tabular}{|c|c|c|c|c|c|}
\hline \multirow{2}{*}{ Total moistures } & Extemal moisture & & & \multirow[b]{2}{*}{7} & \\
\hline & Inherent moisture & & & & \\
\hline \multicolumn{2}{|l|}{ Ash } & & & & \\
\hline \multicolumn{2}{|l|}{ Volatile matter } & $\begin{array}{l}\text { 墨 } \\
\text { 思 }\end{array}$ & & $\frac{n}{w}$ & $\begin{array}{l}\text { w } \\
\text { w } \\
0\end{array}$ \\
\hline \multicolumn{2}{|l|}{ Fixed carbon } & $\begin{array}{l}\text { 点 } \\
\text { 品 } \\
\text { 志 }\end{array}$ & : & 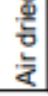 & $\begin{array}{l}8 \\
0 \\
4\end{array}$ \\
\hline
\end{tabular}

Gambar 1. Komposisi analisis proksimat dari basis yang berbeda

Nilai kalor digunakan untuk mengukur kandungan energi dalam suatu bahan bakar. Ada 2 jenis nilai kalor yang sangat sering digunakan yaitu HHV (High Heatinng Value) dan LHV (Low Heating Value). HHV didefinisikan sebagai jumlah dari total panas yang dihasilkan dari bahan bakar biomassa yang di dalamnya termasuk panas laten penguapan dari air dalam bahan bakar dan produk reaksinya, sedangkan untuk LHV merupakan total panas yang dihasilkan dari bahan bakar biomassa akan tetapi tidak termasuk kalor laten penguapan airnya [7]. HHV (High Heating Value) mengacu pada jumlah energi total yang dihasilkan oleh satu kg bahan bakar pada saat bahan bakar tersebut terbakar dengan sempurna. Dalam menentukan nilai HHV bahan bakar sangat memberatkan, karena jika mengikuti prosedur eksperimentalnya, memerlukan bom kalorimeter adiabatik yang diisolasi dengan baik [8].

Nhuchhen dkk. [8] menjelaskan dalam penelitiannya bahwa dalam membuat korelasi baru menggunakan metode kesalahan kuadrat jumlah terkecil pada Microsoft Excel, yang melibatkan nilai volatile matter dan fixed carbon akan tetapi korelasi ini memiliki nilai eror yang cukup besar sekitar $10 \%$. Metode smart approaches digunakan menggunakan model GA-ANFIS, DEANFIS, ANN, LSSVM, dan GARBF serta model empiris (MPR). Dengan mengevaluasi 382 data proksimat dari berbagai jenis biomassa. Model empiris MPR memiliki akurasi tertinggi dibandingkan model yang sudah ada sebelumnya, yang di dalamnya melibatkan 3 variabel terpenting yaitu FC,VM, dan Ash [9]. Nilai HHV juga dapat diprediksi menggunakan nilai dari komposisi unsurnya atau data dari analisa ultimat bahan bakar tersebut, dengan kesalahan relatif rata-rata mendekati $1,2 \%$ [10]. Studi ini dilakukan agar bisa mendapatkan data komposisi unsur dan nilai HHV-nya untuk menjadi data perhitungan dalam analisa gas buang dan kebutuhan udara dalam pembakaran di incinerator PLTSa di Universitas Singaperbangsa Karawang dalam waktu yang sikat dan biaya yang lebih murah serta hasil yang akurat.

\section{LANDASAN TEORI}

\section{A. Pengertian PLTSa}

PLTSa atau yang memiliki kepanjangan Pembangkit Listrik Tenaga Sampah merupakan salah satu pembangkit listrik yang memanfaatkan sampah sebagai bahan bakar utama. Secara garis besar cara kerja pembangkit listrik ini sama dengan PLTU (Pembangkit Listrik Tenaga Uap) yang membedakan hanya sumber panas dari bahan bakarnya. Pada PLTSa nantinya sampah akan dibakar dalam incinerator yang panasnya kemudian akan digunakan untuk memanaskan air yang terdapat pada boiler kemudian uap panas dan bertekanan ini akan disalurkan ke dalam tubin uap yang akan menghasilkan putaran dari dorongan uap tadi terhadap baling-baling yang ada pada turbin uap, kemudian putaran itu akan dialirkan kepada generator yang pada akhirnya akan menghasilkan energi listrik [11].

\section{B. Incinerator}

Incinerator adalah sebuah alat/tungku pembakaran yang berfungsi untuk mengolah limbah yang berbentuk padat yang dikonversikan menjadi materi abu atau gas. Alat ini dapat mengubah ukuran sampah hingga mencapai $50-90 \%$ ukuran awalnya. Incinerator merupakan alat penghancur atau pemusnah limbah yang mempunyai sistem yang terkontrol dan terisolir dari lingkungan sekitarnya. Alat ini dibedakan menjadi dua jenis yaitu batch dan kontinu. Untuk jenis batch sampah dimasukkan hingga kapasitas maksimal dari alat tersebut kemudian melalui proses pembakaran hingga tersisa hasil pembakarannya yang diperoleh dalam satu waktu tertentu. Sedangkan untuk jenis kontinu untuk sampahnya dimasukkan secara terus-menerus selama proses pembakaran terjadi dalam waktu yang berkelanjutan. Dalam pengoperasiannya alat pembakar sampah ini mampu menghasilkan temperatur antara $815^{\circ} \mathrm{C}$ sampai $1.095^{\circ} \mathrm{C}$ [3]. Pada perancangannya banyak faktor yang diperlukan di antaranya sistem pembakaran awal, jumlah sampah yang dibakar, jumlah udara yang dibutuhkan dalam proses pembakaran, serta sistem pengolahan gas buang yang dihasilkan dari pembakaran yang dapat mencemari lingkungan. Adapun jenis incinerator yang pada umunya sering digunakan untuk mengolah limbah padat B3 adalah moving grate, multiple hearth, rotary kiln, fluidized bed, dan fixed gratet. Dari semua macam jenis incinerator yang disebutkan di atas yang memiliki keunggulan ialah jenis rotary kiln karena jenis ini dapat 
mengolah limbah padat, gas dan cair secara simultan, untuk penjelasan lebih lanjutnya sebagai berikut:

\section{a. Rotary kiln}

Rotary kiln merupakan jenis incinerator yang memiliki kerangka silindris serta dilapisi oleh bahan yang tahan terhadap api bersuhu tinggi, yang dipasangkan pada sudut kemiringan yang cukup rendah. Sudut kemiringan dan rotasi pada kiln (tanur) akan menyebabkan bergeraknya limbah melalui tanur yang bersamaan juga untuk meningkatkan limbah yang ada pada tanur bercampur dengan udara. Rotary kiln normalnya memerlukan suatu ruang bakar sekunder untuk memastikan unsur-unsur berbahaya yang ada pada limbah hancur secara menyeluruh. Ruang utama pada jenis ini berfungsi untuk proses pirolisis atau pembakaran limbah padat menjadi limbah gas. Reaksi pembakaran fase gas yang ada pada ruang utama akan disempurnakan di dalam ruang sekunder. Kedua ruangan tersebut pada umumnya akan dilengkapi dengan sistem bahan bakar pembantu. Rotary kiln dalam kerangka silindrisnya akan memutar-mutarkan sampah yang memungkinkan udara tercampur dengan seksama. Kondisi operasional pada jenis ini dapat mencapai suhu sekitar $1500-3000^{\circ} \mathrm{F}$ atau setara dengan 800 $1650^{\circ} \mathrm{C}$. Oleh karena itu incinerator jenis ini memiliki ketahanan yang cukup baik terhadap pembakaran pada suhu bertemperatur tinggi. Sistem jenis ini juga merupakan sistem pengolahan limbah yang paling sering digunakan jika dilihat dari segi kondisi dan jenis limbah yang diolah. Incinerator jenis ini juga dapat diaplikasikan untuk berbagai jenis limbah padat dan sludge, gas maupun cair. Jenis ini dapat mengolah limbah padat, gas, maupun cair dalam kuantitas yang cukup besar serta juga dapat beroperasi secara batch yang memungkinkan lebih fleksibel dibandingkan dengan cara kontinu. Jenis rotary kiln incinerator ditunjukkan pada gambar 2 [11].

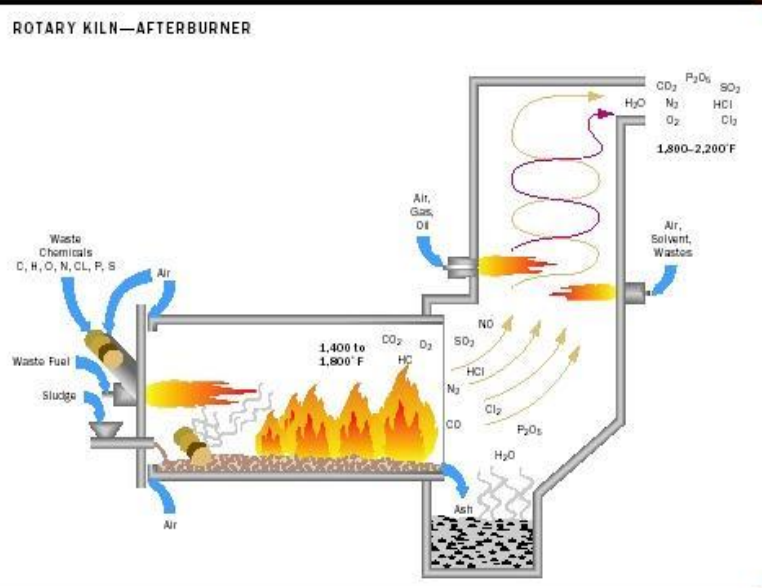

Gambar 2. Rotary kiln incinerator

b. Multiple hearth

Multiple hearth incinerator terdiri dari kerangka yang dilapisi baja tahan panas dengan serangkaian tungku (hearth) yang disusun secara vertikal, satu tungku di bagian atas tungku lainnya dan umumnya tungku tersebut berjumlah 5 sampai 8 buah, shaft rabble arms beserta rabble teethnya memiliki kecepatan putaran berkisar dari 3/4 sampai 2 RPM. Sampah dimasukkan dari bagian atas tungku secara terus menerus (kontinyu) dan hasil dari proses pembakaran yang berupa abu akan dikeluarkan melalui silo. Pembakar akan dipasang pada bagian sisi dari tungku pembakar yang di mana proses pembakaran terjadi. Udara masuk melalui bagian bawah tungku. Jenis limbah yang dapat diolah dengan jenis ini mempunyai kandungan padatan minimum di antara 15 sampai 50 persen berat limbahnya. Untuk limbah yang memiliki kandungan padatan di bawah dari 15 persen akan memiliki sifat seperti cairan dibandingkan dengan padatan, serta limbah ini cenderung akan mengalir di dalam tungku dan fungsi dari rabble akan menjadi kurang efektif. Jika kandungan padatannya di atas 50 persen beratnya, makan akan bersifat kental dan cenderung akan menutupi rabble teeth-nya. Udara disalurkan dari bagian bawah tungku dan naik melewati tungku serta membawa hasil dari pembakaran yang serta partikel-partikel abu. Jenis multiple hearth incinerator ditunjukkan pada gambar 3 [11].

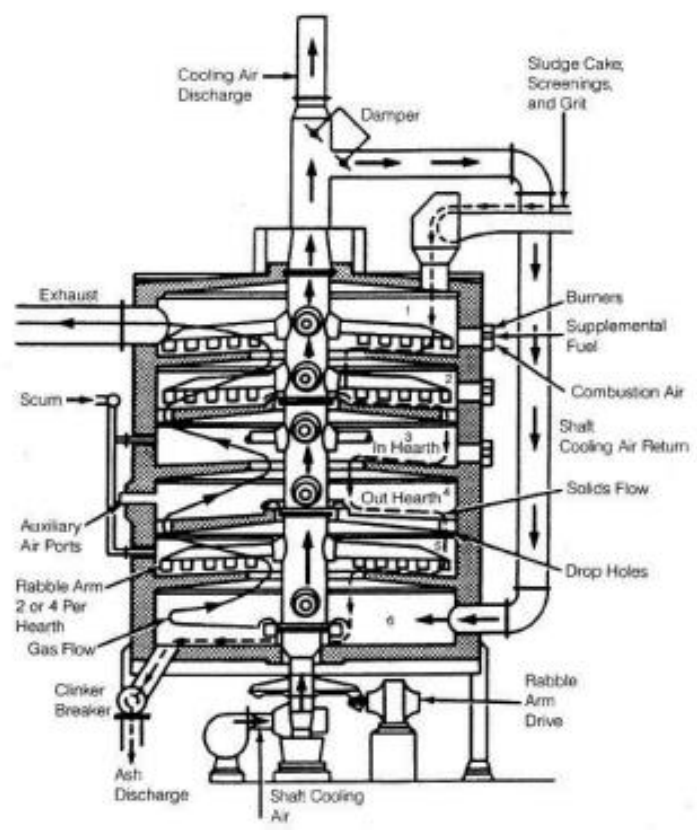

Gambar 3. Multiple hearth incinerator

\section{c. Fluidized bed}

Fluidized bed incinerator merupakan tungku pembakar yang menggunakan media pasir kuarsa atau pasir silika sebagai pengaduk, sehingga menjadikan percampuran yang homogen antara butiran-butiran pasir dengan udara. Pencampuran yang konstan antara keduanya menyebabkan terjadinya laju perpindahan panas yang cukup efektif serta terjadinya pembakaran yang sempurna. Fluidized bed memiliki 9 silindris yang tegak lurus 
dengan kerangka baja yang dilapisi bahan tahan panas, berisi pasir dan penyebar udara. Jenis ini normalnya memiliki ukuran diameter dari 9 sampai 34 kaki atau setara dengan 3 sampai 11 meter. Fluidized bed incinerator telah banyak digunakan untuk berbagai macam jenis limbah baik itu limbah perkotaan maupun limbah lumpur. Reaktor unggun atau hamparan fluidasi (fluidized bed) dapat meningkatkan penyebaran dari limbah sampah yang akan masuk disertai dengan proses pemanasan yang cukup cepat hingga pada temperatur pengapiannya (ignition) dan meningkatkan waktu kontak yang cukup serta kondisi perpaduan yang baik dalam proses pembakaran terjadi. Pada keadaan normal pembakaran terjadi dengan sendirinya, kemudian limbah hancur dengan waktu yang cukup cepat, kering dan terbakar dalam butiran-butiran pasir yang ada. Laju pembakaran limbah juga meningkat dikarenakan adanya kontak langsung dengan partikel-partikel pasir yang sudah dalam keadaan panas. Aliran dari udara menyebabkan tertiupnya abu dari hamparan pasir. Untuk gas-gas yang dihasilkan dari proses pembakaran biasanya akan diproses kembali menggunakan wet scrubber kemudian sisa abunya dibuang dengan cara landfill. Jenis fluidized bed incinerator ditunjukkan pada gambar 4 [11].

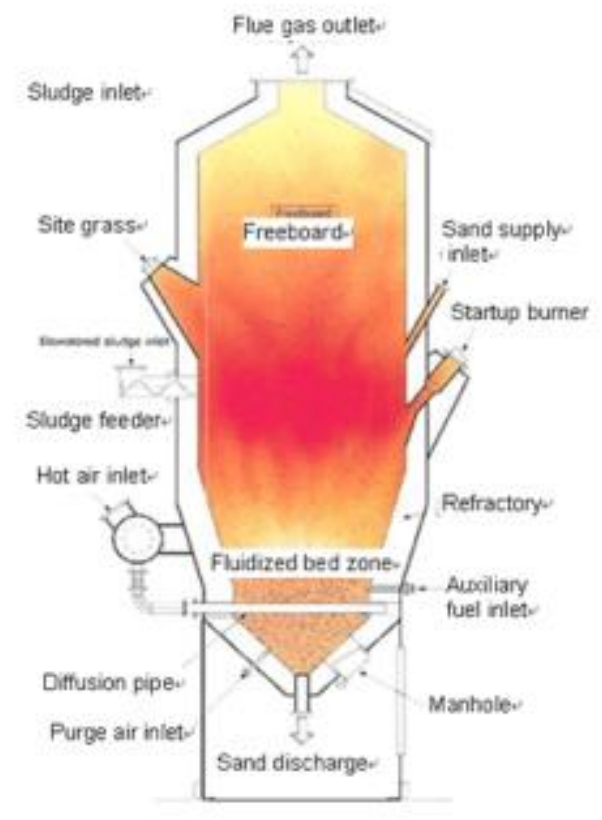

Gambar 4. Fluidized bed incinerator.

d. Moving grate

Moving grate incinerator adalah incinerator yang tidak memerlukan proses pencacahan dan penyortiran limbah yang akan digunakan dan jenis ini juga dapat mengakomodasi kuantitas yang cukup besar serta variasi dari nilai kalor dan komposisi limbah itu sendiri. Dengan penggunaan lebih dari 100 tahun, sistem moving grate ini mempunyai rekam jejak yang lama dalam menanggulangi limbah campuran. Dilaporkan antara tahun 2003 sampai 2020 sekurang-kurangnya 200 moving grate incinerator telah digunakan di seluruh negara dalam mengolah limbah. Dibandingkan dengan jenis yang lain, jenis moving grate memiliki kapasitas pabrik dan kapasitas unit yang paling tinggi. Jenis ini dapat beroperasi dengan waktu 8.000 jam per tahun dengan satu kali setiap bulannya dilakukan inspeksi dan maintenance. Moving grate incinerator menggunakan gratenya untuk mengerakkan limbah pada ruang pembakaran agar terciptanya pembakaran yang efektif dan sempurna. Untuk jenis ini tidak diperlukannya pretreatment pada limbah untuk memudahkan proses dalam skala yang besar dan variasi yang banyak. Kebanyakan dari jenis ini memiliki pemasok sampah hidrolik sebagai jalur masuk sampah ke dalam ruang bakar, sebuah boiler sebagai penerima panas, dan APC (Air Pollution Control) sebagai pembersih zat-zat berbahaya pada gas buang, dan discharge unit untuk mengatasi fly ash. Udara ataupun water-cooled merupakan pusat utama dalam proses jenis ini dan itu terbuat dari paduan khusus yang tahan pada temperatur tinggi dan terhindar dari korosi dan erosi. Prinsip kerja dari jenis moving grate incinerator ditunjukan pada gambar 5 [11].

Gambar 5. Moving grate incinerator.

Adapun pada rancangan PLTSa UNSIKA desain incinerator yang digunakan ditunjukkan pada gambar 6 .

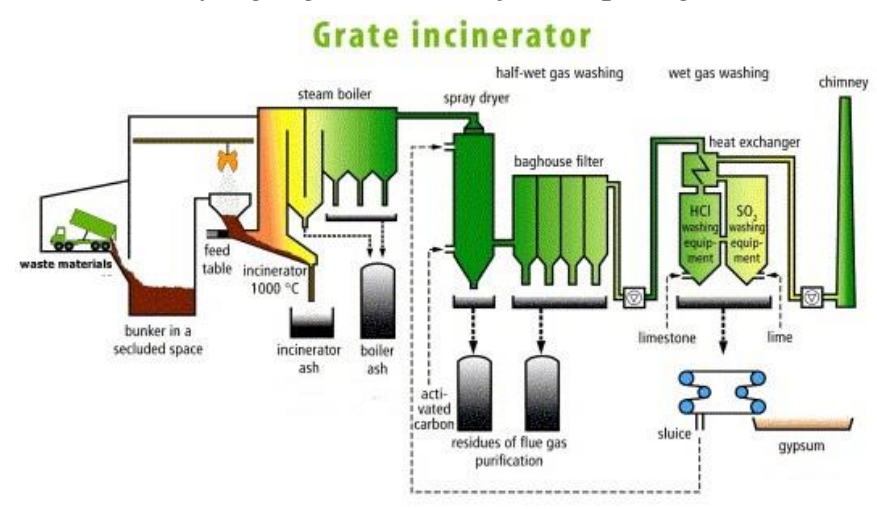

Gambar 6. Rancangan incinerator PLTSa UNSIKA.

\section{Kualitas bahan bakar}

Setiap jenis bahan bakar memiliki sifat yang berbedabeda, terutama jika dilihat dari kualitasnya. Kualitas bahan bakar adalah sifat kimia dan fisika yang mempengaruhi potensi kegunaannya dari bahan bakar itu sendiri. Kualitas bahan bakar dapat ditentukan berdasarkan dengan analisis pada laboratorium maupun menggunakan korelasi, pada umumnya kualitas bahan bakar dibagi menjadi dua yaitu analisis proksimat dan ultimat. Analisis proksimat digunakan untuk mengetahui kadar air (moisture), karbon padat (fixed carbon), kadar abu (ash), dan zat terbang (volatile matter), sedangkan untuk analisis ultimate digunakan untuk mengetahui kandungan unsur kimia pada 
bahan bakat tersebut meliputi: karbon, oksigen, sulfur, hidrogen, nitrogen [4].

a. Analisis Proksimat

Analisis proksimat menunjukkan banyaknya kadar air, kadar abu, bahan mudah menguap dan fixed carbon dalam satuan persen. Nilai panas/kalor pada bahan bakar secara langsung dipengaruhi oleh bahan yang mudah menguap dan fixed carbon. Fixed carbon merupakan zat yang bertindak sebagai pembangkit utama dalam proses pembakaran. Volatile matter yang tinggi menunjukkan mudahnya bahan bakar untuk menyala. Sedangkan kadar abu dan kadar air adalah hal yang penting dalam perancangan grate tungku, volume pembakaran, dan peralatan kendali polusi.

b. Analisis Ultimat

Analisa pada laboratorium untuk menentukan kandungan karbon $(\mathrm{C})$, hidrogen $(\mathrm{H})$, sulfur $(\mathrm{S})$, oksigen $(\mathrm{O})$, dan nitrogen $(\mathrm{N})$ dalam bahan bakar padat dengan metode tertentu. Kandungan itu dinyatakan dalam persen dan basis hasil tertentu.

\section{Kalor}

Kalor adalah sesuatu yang berbentuk energi. Jika sesuatu zat melepaskan ataupun menerima kalor, maka akan ada dua kemungkinan yang akan terjadi. Kemungkinan pertama ialah terjadinya perubahan pada temperatur pada zat tersebut, kalor yang terlibat pada kejadian seperti ini biasa disebut dengan kalor sensibel. Kemungkinan yang kedua ialah terjadinya perubahan fase pada zat tersebut, kalor yang terlibat pada kejadian ini disebut dengan kalor laten. Pada suatu zat umumnya terdapat dua jenis kalor laten, yaitu kalor laten pembekuan atau peleburan dan kalor laten pengembunan atau penguapan. Kalor laten pada suatu zat biasanya lebih besar dari kalor sensibelnya, hal ini disebabkan karena untuk mengubah suatu fase dalam zat membutuhkan energi yang cukup besar. Adapun persamaan pada kalor laten dan sensibel sebagai berikut [12].

$Q_{S}=m \cdot C_{p} \cdot \Delta T$

$Q_{L}=m \cdot h_{1}$

dengan,

$Q_{L}=$ kalor laten $(\mathrm{J})$

$Q_{S}=$ kalor sensibel $(\mathrm{J})$

$m$ = massa zat yang mengalami perubahan temperatur $(\mathrm{kg})$

$C_{p}=$ kalor jenis zat $(\mathrm{J} / \mathrm{kg} . \mathrm{K})$

$\Delta T=$ perubahan temperatur yang terjadi $(\mathrm{K})$

$h_{1}=$ kalor laten $(\mathrm{kJ} / \mathrm{kg})$

Adapun energi yang diperlukan untuk mengubah fase dan temperatur air ialah sebagai berikut.

Gambar 7. Energi yang dibutuhkan untuk mengubah temperatur dan fase air

\section{E. Nilai kalor}

Nilai kalor ialah banyaknya kalor atau panas yang dapat dihasilkan oleh sesuatu bahan bakar pada saat proses pembakaran sempurna. Nilai kalor pada umumnya dibagi

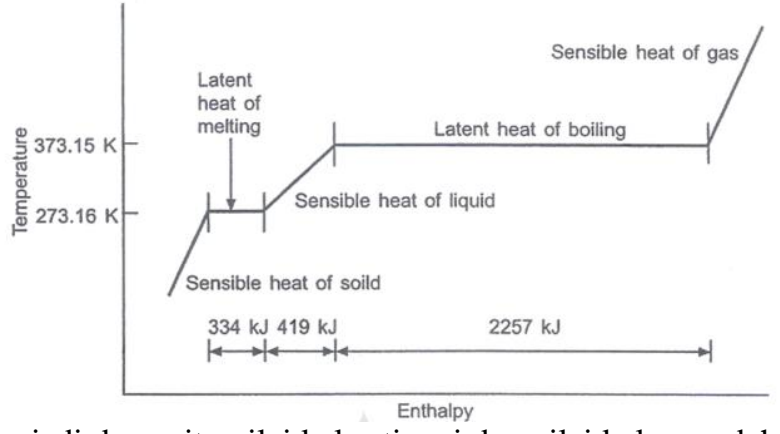

menjadi dua yaitu nilai kalor tinggi dan nilai kalor rendah [8].

a. Nilai kalor tinggi, dengan nama lain Gross atau High Heating Value, adalah Total panas yang dihasilkan ketika bahan bakar benar-benar terbakar dan mengandung panas dari penguapan udara.

b. Nilai kalor rendah, dengan nama lain Net atau Low Heating Value, adalah Panas bersih dihasilkan ketika bahan bakar benar-benar terbakar dan tidak mengandung panas dari penguapan udara. Untuk mengetahui nilai LHV dapat menggunakan persamaan berikut

$L H V^{r}=H H V^{r}-2453 \cdot\left(W^{r}+8,94 H^{r}\right)$

dengan,

$\mathrm{HHV}=$ High Heating Value

LHV = Low Heating Value

$\mathrm{W}=$ kadar air/kelembaban

F. Basis hasil analisis bahan bakar padat

Basis dalam hasil analisis kimia bahan bakar merupakan dasar yang dipakai untuk menyatakan nilai dari suatu parameter dan menginterpretasikan nilai tersebut pada kondisi tertentu. Basis yang sering digunakan adalah sebagai berikut [7].

a. As received ( $\mathrm{ar} / \mathrm{r})$ : menunjukkan data, dinyatakan sebagai persentase terhadap bahan bakar padat total termasuk kandungan air sebagai mana seperti keadaan diambil dari lapangan.

b. Air dried basis (ad): menunjukkan data, dinyatakan sebagai persentase terhadap bahan bakar padat kecuali kandungan air.

c. Dry basis (db/d) : menunjukkan data, dinyatakan sebagai persentase bahan bakar padat tanpa kandungan air.

d. Dry ash free (daf) : menunjukkan data, dinyatakan sebagai persentase terhadap komponen bahan bakar padat zat terbang dan karbon tertambat atau persentase bahan bakar padat tanpa kandungan air dan kandungan abu.

G. Prediksi komposisi unsur menggunakan analisis proksimat

Beberapa penelitian terdahulu telah memberikan hubungan untuk memprediksi komposisi unsur dan HHV dari biomassa menggunakan analisa proksimat dan ultimat [13]. Parikh dkk. [5] mempertimbangkan Volatile Matter 
(VM) dan Fixed Carbon (FC) untuk memprediksi C, H, O dengan persamaan sebagai berikut:

$$
\begin{aligned}
& C^{r}=0,637 F C+0,455 V M \\
& H^{r}=0,052 F C+0,062 V M \\
& O^{r}=0,304 F C+0,476 V M
\end{aligned}
$$

Kesalahan absolute rata-rata dari persamaan (4)-(6) masing-masing $3,21 \%, 4,79 \%$, dan $3,4 \%$ dengan kesalahan bias masing-masing $0,21 \%, 0,15 \%$, dan $0,49 \%$ dalam memprediksi unsur $\mathrm{C}, \mathrm{H}$, dan $\mathrm{O}$ untuk biomassa raw [13]. Shen dkk. [6] mengembangkan berdasarkan hubungan antara fixed carbon, volatile matter dan Ash Content (ASH) dari biomassa raw untuk memprediksi komposisi unsurnya, dengan persamaan sebagai berikut:

$$
\begin{aligned}
& C^{r}=0,635 F C+0,460 V M-0,095 A S H \\
& H^{r}=0,059 F C+0,060 V M+0,010 A S H \\
& O^{r}=0,340 F C+0,469 V M-0,023 A S H
\end{aligned}
$$

Kesalahan absolute rata-rata dari persamaan (7)-(9) masing-masing $3.17 \%, 4.47 \%$, dan $3.16 \%$, dengan kesalahan bias masing-masing $0.19 \%, 0.34 \%$, dan $0.19 \%$ [13].

\section{H. Prediksi nilai HHV menggunakan analisis proksimat dan ultimat}

Dalam studinya Dashti dkk. [9] dalam memprediksi nilai HHV biomassa, mereka menggunakan metode smart approaches dengan GA-ANFIS, DEANFIS, ANN, LSSVM, dan GARBF serta model empiris (MPR). Mereka mengembangkan dan mengevaluasi 382 data proksimat dari berbagai jenis biomassa. Efektivitas model untuk berbagai model diuji. Model GARBF yang dikembangkan menunjukkan akurasi tertinggi untuk memprediksi nilai HHV bahan bakar biomassa dan dapat dianggap sebagai metode potensial untuk teknik cepat dan murah. Selain itu, model MPR memiliki akurasi tertinggi dibandingkan dengan model empiris yang sudah ada sebelumnya. Dalam studinya, mereka menggunakan 3 variabel terpenting yaitu fixed carbon, volatile matter, dan ash yang memiliki persamaan sebagai berikut.

$H H V^{d}=-0,0038\left(-19,9812 \cdot F C^{1,2259}-1,0298 \cdot\right.$

$\left(10^{-13}\right) \cdot\left(V M^{8,0664}\right)+0,1026 \cdot\left(A S H^{2,4231}\right)-1,2065 \cdot$ $\left(10^{-7}\right) \cdot\left(F C \cdot A S H^{4,6653}\right)+0,0228 \cdot(F C \cdot V M \cdot A S H)-$ $\left.0,2511 \cdot\left(\frac{V M}{A S H}\right)\right)-0,0478 \cdot\left(\frac{F C}{V M}\right)+15,7199$

$[\mathrm{MJ} / \mathrm{kg}]$

Huang dan Lo [10] menyajikan korelasi semi empiris dalam memprediksi nilai HHV biomassa berdasarkan komposisi unsurnya. Berdasarkan hasil kesalahan relatif dan regresi linier, korelasi yang disajikan ini memberikan prediksi nilai HHV yang lebih akurat dibandingkan dengan persamaan korelasi yang terlibat dalam penelitian.
Dengan persamaan korelasi sebagai berikut yang menggunakan basis dry basis.

$$
\begin{aligned}
& H H V^{d}=0,3443 C+1,192 H-0,113 O-0,024 N+ \\
& 0,093 S[M J / k g]
\end{aligned}
$$

\section{METODE PENELITIAN/EKSPERIMEN}

\section{A. Tahapan pada penelitian}

Secara garis besar penelitian ini dimulai dari menentukan komposisi apa saja yang terdapat pada sampel dan seberapa banyak jumlah dari masing-masing komposisi yang di tentukan. Kemudian sampel diolah melalui 4 proses pengolahan yaitu pemilihan, pencacahan, karbonasi (pengarangan), dan penghalusan. Kemudian sampel diuji kandungan fixed carbon, volatile matter, ash, dan kadar airnya menggunakan metode ASTM D3173 (kadar air), ASTMD3174 (ash), ASTM D3175 (vilatile matter), dan by difference untuk kandungan fixed carbonnya. Lalu data yang diperoleh di kelompokkan sesuai dengan basis hasilnya, lalu data tersebut melalui proses perhitungan. Diagram alir penelitian ditunjukkan pada gambar 8 .

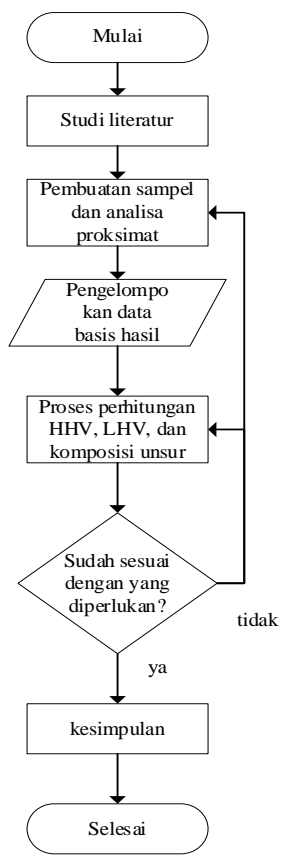

Gambar 8. Diagram alir penelitian

\section{B. Basis hasil analisis bahan bakar}

Penggunaannya basis-basis dapat dikonversikan dengan perumusan pada tabel 1 .

Tabel 1. Konversi basis hasil analisa bahan bakar

\begin{tabular}{cccc}
\cline { 2 - 3 } $\begin{array}{l}\text { Untuk } \\
\text { memperoleh- } \\
\text {-kalikan }\end{array}$ & Air dry & Dry basis & As recieved \\
\cline { 2 - 3 } ar dengan & $\frac{100-I M \%}{100-T M \%}$ & $\frac{100}{100-T M \%}$ & - \\
ad dengan & - & $\frac{100}{100-I M \%}$ & $\frac{100-T M \%}{100-I M \%}$ \\
db dengan & $\frac{100-I M \%}{100}$ & - & $\frac{100-T M \%}{100}$ \\
\hline
\end{tabular}


Untuk daf, kalikan db dengan $\frac{100}{100-A}$.

dengan,

$\mathrm{TM}=$ Total Moisture atau kadar air

$\mathrm{IM}=$ Inherent Moisture

\section{Proses perhitungan}

Proses ini meliputi perhitungan nilai komposisi unsur CHO, HHV, dan LHV dari suatu bahan bakar.

1. Komposisi unsur $\mathrm{CHO}$

Dalam perhitungan ini membutuhkan data dalam basis as recieved dalam penggunaannya, dengan rumusan sebagai berikut untuk setiap unsurnya.

$C^{r}=0,635 F C+0,460 V M-0,095 A S H$

$H^{r}=0,059 F C+0,060 V M+0,010 A S H$

$O^{r}=0,340 F C+0,469 V M-0,023 A S H$

\section{Nilai HHV}

Dalam perhitungannya membutuhkan data dalam basis dry basis, dengan persamaan sebagai berikut.

$$
\begin{aligned}
& H H V^{d}=- 0,0038\left(-19,9812 \cdot F C^{1,2259}-1,0298\right. \\
&\left(10^{-13}\right) \cdot\left(V M^{8,0664}\right)+0,1026 \cdot\left(A S H^{2,4231}\right) \\
&-1,2065 \cdot \cdot\left(10^{-7}\right) \cdot\left(F C \cdot A S H^{4,6653}\right)+0,0228 \\
&\left.\cdot(F C \cdot V M \cdot A S H)-0,2511 \cdot \frac{V M}{A S H}\right)-0,0478 \\
& \cdot\left(\frac{F C}{V M}\right)+15,7199 \quad[\mathrm{MJ} / \mathrm{kg}]
\end{aligned}
$$

\section{Nilai LHV}

Dalam perhitungannya membutuhkan data dalam basis as recieved, dengan tambahan kadar air (W), dengan perumusan sebagai berikut.

$L H V^{r}=H H V^{r}-2453 \cdot\left(W^{r}+8,94 H^{r}\right)$

\section{HASIL DAN PEMBAHASAN}

Penelitian ini melibatkan 3 sampel bahan bakar sampah dengan komposisi sampel bahan bakar meliputi:
a. daun mangga,
b. daun pisang,
c. daun ketapang, dan
d. kertas

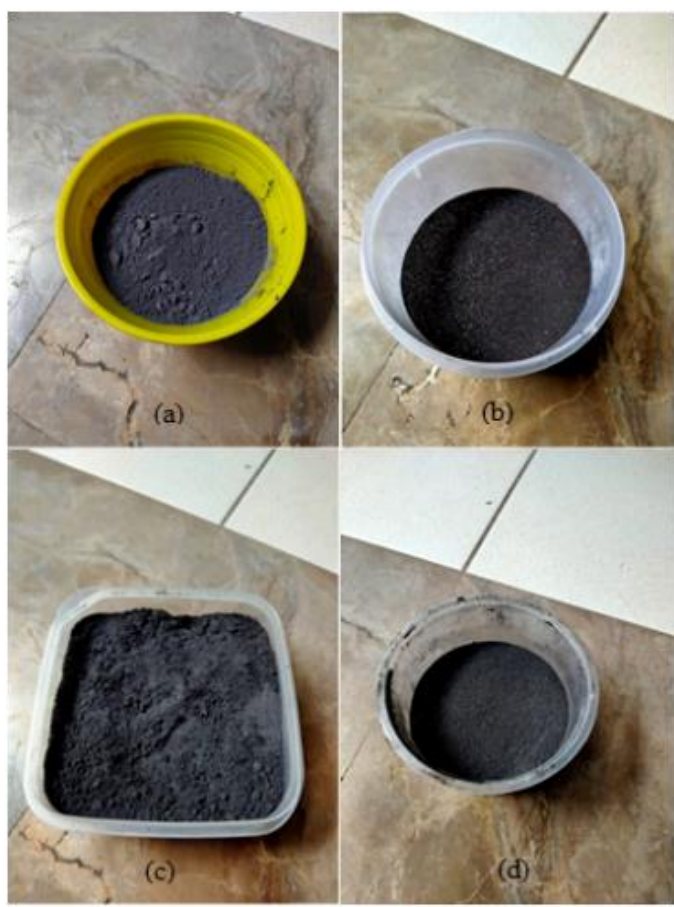

Gambar 9. Karbon sampah; (a) kertas, (b) daun mangga, (c) daun pisang, dan (d) daun ketapang.

Komposisi masing-masing ditunjukkan pada tabel 2.

\begin{tabular}{|c|c|c|c|c|}
\hline \multirow{2}{*}{ No. } & \multirow{2}{*}{ Parameter } & \multirow{2}{*}{ Satuan } & \multicolumn{2}{|c|}{ Basis hasil } \\
\hline & & & As recieved & Dry basis \\
\hline \multirow[t]{5}{*}{1} & Sampel A & & & \\
\hline & -Kadar air & $\% \mathrm{~m}$ & 3,66 & - \\
\hline & -Kadar abu & $\% \mathrm{~m}$ & 30,60 & 31,76 \\
\hline & -Volatile matter & $\% \mathrm{~m}$ & 34,11 & 35,41 \\
\hline & -Fixed Carbon & $\% \mathrm{~m}$ & 31,63 & 32,83 \\
\hline \multirow[t]{5}{*}{2} & Sampel B & & & \\
\hline & -Kadar air & $\% \mathrm{~m}$ & 4,45 & - \\
\hline & -Kadar abu & $\% \mathrm{~m}$ & 29,24 & 30,60 \\
\hline & -Volatile matter & $\% \mathrm{~m}$ & 34,59 & 36,20 \\
\hline & -Fixed Carbon & $\% \mathrm{~m}$ & 31,72 & 33,20 \\
\hline \multirow[t]{5}{*}{3} & Sampel C & & & \\
\hline & -Kadar air & $\% \mathrm{~m}$ & 4,15 & - \\
\hline & -Kadar abu & $\% \mathrm{~m}$ & 29,22 & 30,49 \\
\hline & -Volatile matter & $\% \mathrm{~m}$ & 34,85 & 36,36 \\
\hline & -Fixed Carbon & $\% \mathrm{~m}$ & 31,77 & 33,15 \\
\hline
\end{tabular}

Tabel 2. Komposisi masing-masing sampel bahan bakar

\begin{tabular}{ccccc}
\hline \multirow{2}{*}{$\begin{array}{c}\text { Jenis } \\
\text { Sampel }\end{array}$} & Kertas & $\begin{array}{c}\text { Daun } \\
\text { mangga }\end{array}$ & $\begin{array}{c}\text { Daun } \\
\text { pisang }\end{array}$ & $\begin{array}{c}\text { Daun } \\
\text { ketapang }\end{array}$ \\
\cline { 2 - 5 } & 25 & 25 & 25 & 25 \\
A & 20 & 40 & 25 & 15 \\
B & 35 & 25 & 25 & 15 \\
C & 35 & & \\
\hline
\end{tabular}

Hasil analisis proksimat ditunjukkan pada tabel 3.

Tabel 3. Data analisa proksimat sampel sampah 
Data yang diperoleh kemudian dihitung, dengan terlebih dahulu menyamakan basisnya sesuai dengan kebutuhan dalam persamaan, dan diperoleh hasil komposisi unsurnya untuk Sampel A dengan basis as recieved maka diperoleh nilai $\mathrm{C}^{\mathrm{r}}, \mathrm{H}^{\mathrm{r}}$, dan $\mathrm{O}^{\mathrm{r}}$ sebagai berikut.

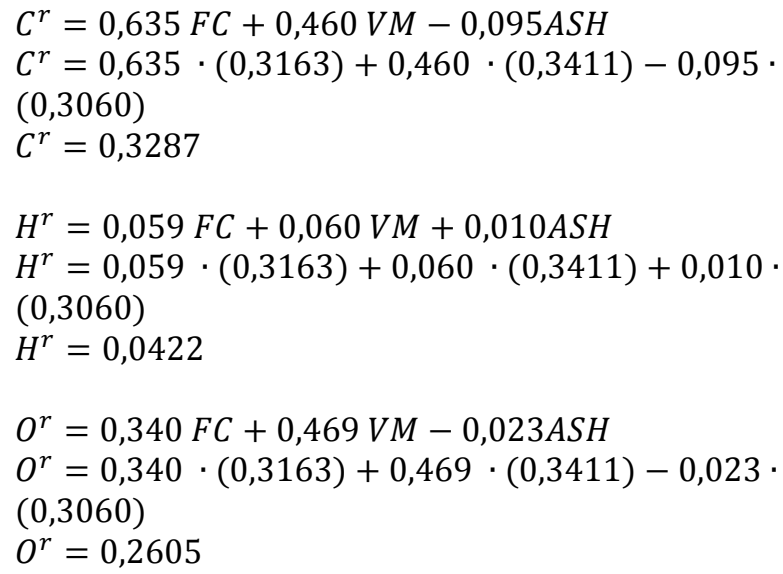

Sampel B dengan basis as recieved maka diperoleh nilai $\mathrm{C}^{\mathrm{r}}, \mathrm{H}^{\mathrm{r}}$, dan $\mathrm{O}^{\mathrm{r}}$ sebagai berikut.

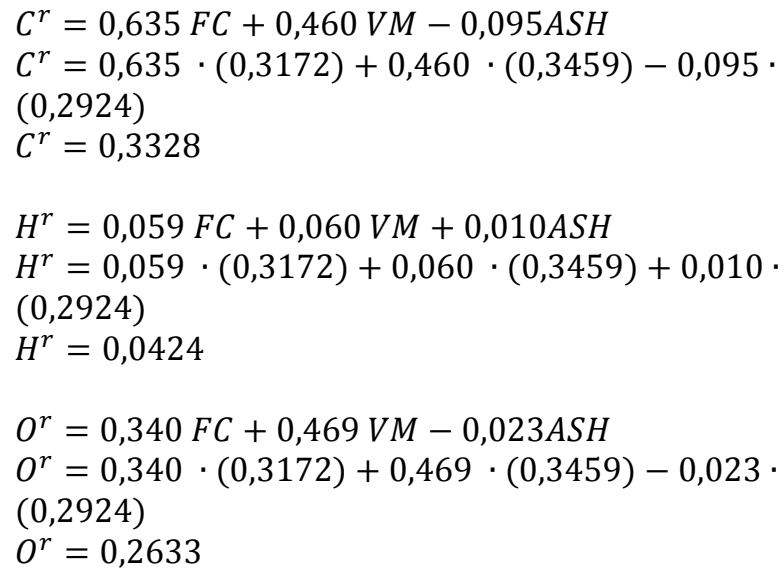

Sampel C dengan basis as recieved maka diperoleh nilai $\mathrm{C}^{\mathrm{r}}, \mathrm{H}^{\mathrm{r}}$, dan $\mathrm{O}^{\mathrm{r}}$ sebagai berikut.



Sedangkan keseluruhan nilai disajikan pada tabel 4 .
Tabel 4. Data komposisi unsur $\mathrm{CHO}$ sampah

\begin{tabular}{ccccc}
\hline \multirow{2}{*}{ No. } & \multirow{2}{*}{ Jenis sampel } & \multicolumn{3}{c}{ Massa } \\
\cline { 3 - 5 } & & $C^{r}$ & $H^{r}$ & $O^{r}$ \\
\hline 1 & Sampel A & 0,3287 & 0,0422 & 0,2605 \\
\hline 2 & Sampel B & 0,3328 & 0,0424 & 0,2633 \\
\hline 3 & Sampel C & 0,3343 & 0,0426 & 0,2647 \\
\hline
\end{tabular}

Kemudian data sampel A yang berbasis dry basis digunakan dalam menghitung $\mathrm{HHV}$ dry basis, lalu dikonversikan ke dalam basis as recieved seperti berikut:

$$
\begin{aligned}
H H V^{d}=-0,0038 & \left(-19,9812 \cdot F C^{1,2259}-1,0298\right. \\
& \cdot\left(10^{-13}\right) \cdot\left(V M^{8,0664}\right)+0,1026 \\
& \cdot\left(A S H^{2,4231}\right)-1,2065 \cdot\left(10^{-7}\right) \\
& \cdot\left(F C \cdot A S H^{4,6653}\right)+0,0228 \\
& \left.\cdot(F C \cdot V M \cdot A S H)-0,2511 \cdot\left(\frac{V M}{A S H}\right)\right) \\
& -0,0478 \cdot\left(\frac{F C}{V M}\right)+15,7199 \\
H H V^{d}=-0,0038 & \left(-19,9812 \cdot\left(0,3283^{1,2259}\right)\right. \\
& -1,0298 \cdot\left(10^{-13}\right) \cdot\left(0,3541^{8,0664}\right) \\
& +0,1026 \cdot\left(0,3176^{2,4231}\right)-1,2065 \\
& \cdot\left(10^{-7}\right) \cdot\left(0,3283 \cdot 0,3176^{4,6653}\right) \\
& +0,0228 \cdot(0,3283 \cdot 0,3541 \cdot 0,3176) \\
& \left.-0,2511 \cdot\left(\frac{0,3541}{0,3176}\right)\right)-0,0478 \\
& \cdot\left(\frac{0,3283}{0,3541}\right)+15,7199
\end{aligned}
$$

$H H V^{d}=15,696001 \mathrm{MJ} / \mathrm{kg}$

$H H V^{d}=15696,001 \mathrm{~kJ} / \mathrm{kg}$, dan dikonversikan ke as recieved basis maka akan menjadi.

$$
\begin{aligned}
& H H V^{r}=H H V^{d} \cdot \frac{100-T M \%}{100} \\
& H H V^{r}=15696,001 \cdot \frac{100-3,66 \%}{100} \\
& H H V^{r}=15690,257 \mathrm{~kJ} / \mathrm{kg}
\end{aligned}
$$

Data sampel B yang berbasis dry basis digunakan dalam menghitung HHV dry basis, lalu dikonversikan ke dalam basis as recieved seperti berikut ini:

$$
\begin{aligned}
H H V^{d}=-0,0038 & \left(-19,9812 \cdot F C^{1,2259}-1,0298\right. \\
& \cdot\left(10^{-13}\right) \cdot\left(V M^{8,0664}\right)+0,1026 \\
& \cdot\left(A S H^{2,4231}\right)-1,2065 \cdot\left(10^{-7}\right) \\
& \cdot\left(F C \cdot A S H^{4,6653}\right)+0,0228 \\
& \left.\cdot(F C \cdot V M \cdot A S H)-0,2511 \cdot\left(\frac{V M}{A S H}\right)\right) \\
& -0,0478 \cdot\left(\frac{F C}{V M}\right)+15,7199
\end{aligned}
$$




$$
\begin{aligned}
H H V^{d}=-0,0038 & \left(-19,9812 \cdot\left(0,3320^{1,2259}\right)\right. \\
& -1,0298 \cdot\left(10^{-13}\right) \cdot\left(0,3620^{8,0664}\right) \\
& +0,1026 \cdot\left(0,3060^{2,4231}\right)-1,2065 \\
& \cdot\left(10^{-7}\right) \cdot\left(0,3320 \cdot 0,3060^{4,6653}\right) \\
& +0,0228 \cdot(0,3320 \cdot 0,3620 \cdot 0,3060) \\
& \left.-0,2511 \cdot\left(\frac{0,3620}{0,3060}\right)\right)-0,0478 \\
& \cdot\left(\frac{0,3320}{0,3620}\right)+15,7199
\end{aligned}
$$$$
H H V^{d}=15,696815 \mathrm{MJ} / \mathrm{kg}
$$$$
H H V^{d}=15696,815 \mathrm{~kJ} / \mathrm{kg} \text {, dan dikonversikan ke as }
$$
recieved basis maka akan menjadi.

$H H V^{r}=H H V^{d} \cdot \frac{100-T M \%}{100}$

$H H V^{r}=15696,815 \cdot \frac{100-4,45 \%}{100}$

$H H V^{r}=15689,830 \mathrm{~kJ} / \mathrm{kg}$

Data sampel C yang berbasis dry basis digunakan dalam menghitung HHV dry basis, lalu dikonversikan ke dalam basis as recieved seperti berikut:

$$
\begin{aligned}
& H H V^{d}=-0,0038\left(-19,9812 \cdot F C^{1,2259}-1,0298\right. \\
& \cdot\left(10^{-13}\right) \cdot\left(V M^{8,0664}\right)+0,1026 \\
& \cdot\left(A S H^{2,4231}\right)-1,2065 \cdot\left(10^{-7}\right) \\
& \cdot\left(F C \cdot A S H^{4,6653}\right)+0,0228 \\
& \left.\cdot(F C \cdot V M \cdot A S H)-0,2511 \cdot\left(\frac{V M}{A S H}\right)\right) \\
& -0,0478 \cdot\left(\frac{F C}{V M}\right)+15,7199 \\
& H H V^{d}=-0,0038\left(-19,9812 \cdot\left(0,3315^{1,2259}\right)\right. \\
& -1,0298 \cdot\left(10^{-13}\right) \cdot\left(0,3636^{8,0664}\right) \\
& +0,1026 \cdot\left(0,3049^{2,4231}\right)-1,2065 \\
& \cdot\left(10^{-7}\right) \cdot\left(0,3315 \cdot 0,3049^{4,6653}\right) \\
& +0,0228 \cdot(0,3315 \cdot 0,3636 \cdot 0,3049) \\
& \left.-0,2511 \cdot\left(\frac{0,3636}{0,3049}\right)\right)-0,0478 \\
& \cdot\left(\frac{0,3315}{0,3636}\right)+15,7199 \\
& H H V^{d}=15,697047 \mathrm{MJ} / \mathrm{kg} \\
& H H V^{d}=15697,047 \mathrm{~kJ} / \mathrm{kg} \text {, dan dikonversikan ke as } \\
& \text { recieved basis maka akan menjadi. } \\
& H H V^{r}=H H V^{d} \cdot \frac{100-T M \%}{100} \\
& H H V^{r}=15697,047 \cdot \frac{100-4,15 \%}{100} \\
& H H V^{r}=15690,532 \mathrm{~kJ} / \mathrm{kg}
\end{aligned}
$$

Jenis sampah dan sampel lainnya ditunjukkan pada tabel 5 .
Tabel 5. Data HHV sampel sampah

\begin{tabular}{ccc}
\hline & \multirow{2}{*}{ No. } & $\begin{array}{c}\text { Jenis } \\
\text { sampel }\end{array}$ \\
\cline { 3 - 3 } & & $H_{H V^{r}}$ \\
\hline 1 & Sampel A & 15690,26 \\
2 & Sampel B & 15689,83 \\
3 & Sampel C & 15690,53 \\
\hline
\end{tabular}

LHV dihitung sebagai nilai kalor yang benar-benar dapat digunakan oleh sistem karena di dalamnya tidak ada panas laten penguapan dari kelembapan udara, yang disajikan sebagai berikut.

Pada sampel A diperoleh:

$$
\begin{aligned}
& L H V^{r}=H H V^{r}-2453 \cdot\left(W^{r}+8,94 H^{r}\right) \\
& L H V^{r}=15690,26-2453 \cdot(0,0366+8,94 \cdot 0,0422) \\
& L H V^{r}=15689,24 \mathrm{~kJ} / \mathrm{kg}
\end{aligned}
$$

Pada sampel B diperoleh:

$$
\begin{aligned}
& L H V^{r}=H H V^{r}-2453 \cdot\left(W^{r}+8,94 H^{r}\right) \\
& L H V^{r}=15689,83-2453 \cdot(0,0366+8,94 \cdot 0,0424) \\
& L H V^{r}=15688,79 \mathrm{~kJ} / \mathrm{kg} \\
& \text { Pada sampel C diperoleh: } \\
& L H V^{r}=H H V^{r}-2453 \cdot\left(W^{r}+8,94 H^{r}\right) \\
& L H V^{r}=15690,53-2453 \cdot(0,0366+8,94 \cdot 0,0426) \\
& L H V^{r}=15689,50 \mathrm{~kJ} / \mathrm{kg}
\end{aligned}
$$

Sehingga hasil keseluruhan ditunjukkan pada tabel 6.

Tabel 6. Data LHV sampel sampah

\begin{tabular}{ccc}
\hline & \multirow{2}{*}{ No. } & $\begin{array}{c}\text { Jenis } \\
\text { sampel }\end{array}$ \\
\cline { 3 - 3 } & & Energi $\left[\frac{\mathrm{kJ}}{\mathrm{kg}}\right]$ \\
\hline 1 & Sampel A & $L H V^{r}$ \\
\hline 2 & Sampel B & 15689,24 \\
3 & Sampel C & 15688,79 \\
\hline
\end{tabular}

\section{KESIMPULAN}

Jenis-jenis sampel memiliki komposisi kadar air 3-4\%, kadar abu 29-30\%, volatile matter 34-35\%, fixed carbon 31-32\%, sedangkan untuk komposisi unsurnya berkisaran C $32-34 \%$, H 4,2-4,6\%, dan O 26-26,4\%.

Ada dua jenis nilai kalor yaitu HHV dan LHV, untuk HHV sampel A, sampel B, dan sampel C masing-masing sebesar $15690,257 \mathrm{~kJ} / \mathrm{kg}, 15689,830 \mathrm{~kJ} / \mathrm{kg}$, dan 15690,532 $\mathrm{kJ} / \mathrm{kg}$. Sedangkan untuk nilai LHV nya masing-masing sebesar $15689,24 \mathrm{~kJ} / \mathrm{kg}, 15688,79 \mathrm{~kJ} / \mathrm{kg}$, dan 15689,50 $\mathrm{kJ} / \mathrm{kg}$. 
Korelasi antara data analisis proksimat dengan nilai HHV serta komposisi unsur dapat digunakan dalam menghemat biaya dan efisiensi waktu. Jika dilihat dari ketiga hasil sampel yang di uji menunjukkan perbedaan yang signifikan, dan dapat digunakan dalam mengatasi persoalan dalam perancangan, pemanfaatan, dan pengolahan bahan bakar sampah padat. Dapat dilihat juga dari kesalahan relatif dari masing-masing persamaan relatif kecil. Ini akan menjadi perhatian khususnya dalam konteks di mana perlatan yang mutakhir dan mahal untuk pengujian komponen unsur eksperimental tidak selalu tersedia [14].

\section{UCAPAN TERIMA KASIH}

Terima kasih kepada pihak yang terkait secara langsung maupun tidak langsung dan khusus untuk laboratorium BTBRD BPPT yang telah mengizinkan untuk melakukan pengujian proksimat sampel bahan bakar sampah.

\section{REFERENSI}

[1] G. L. Sari, Kajian potensi pemanfaatan sampah plastik menjadi bahan bakar cair, Al-Ard Jurnal Teknik Lingkungan, vol. 3, no. 1, 2017, pp. 06-13.

[2] M. Yuliani, Insinerasi untuk pengolahan sampah kota, $J R L$, vol. 9, no. 1, 2016, pp. 89-96.

[3] B. Martana, S. Sulasminingsih, and M. A. Lukmana, Perencanaan dan uji performa alat pembakar sampah organik, Bina Teknika, vol. 13, no. 1, 2017, pp. 65-71.

[4] Sepfitrah, Analisis proximate kualitas batubara hasil tambang di Riau (studi kasus Logas, Selensen dan Pangkalan Lesung), Jurnal Sainstek, vol. 4, no .1, 2016, pp. 18-26.

[5] J. Parikh, S. A. Channiwala, and G. K. Ghosal, A correlation for calculating elemental composition from proximate analysis of biomass materials, Fuel, vol. 86, issues 12-13, 2006, pp. 1710-1719.DOI: 10.1016/j.fuel.2006.12.029.

[6] J. Shen, S. Zhu, X. Liu, H. Zhang, and J. Tan, The prediction of elemental composition of biomass based on proximate analysis, Energy Convers. Manag., vol. 51, issue 5, 2009, pp. 983-987. DOI: 10.1016/j.enconman.2009.11.039.

[7] J. Cai et al., Review of physicochemical properties and analytical characterization of lignocellulosic biomass, Renew. Sustain. Energy, vol. 76, 2017, pp. 1-50. DOI: 10.1016/j.rser.2017.03.072.

[8] D. R. Nchuchen and M. T. Afzal, HHV predicting correlations for torrefied biomass using proximate and ultimate analyses, Bioengineering, vol. 4, no. 1, 2016, pp. 1-15. DOI: 10.3390/bioengineering4010007.

[9] A. Dashti, A. S. Noushabadi, M. Raji, A. Razmi, S. Ceylan, and A. H. Mohammadi, Estimation of biomass higher heating value (HHV) based on the proximate analysis: Smart modeling and correlation, Fuel, vol. 257, 2019, pp. 1-11. DOI: 10.1016/j.fuel.2019.115931.

[10] Y.-F. Huang and S.-L. Lo, Predicting heating value of lignocellulosic biomass based on elemental analysis, Energy, vol. q9q, 2019, pp. 1-7. DOI: 10.1016/j.energy.2019.116501.

[11] E. M. Aulawi, Rancang bangun alat insinerator untuk pembangkit listrik tenaga sampah (PLTSa) di UNSIKA, Skripsi, Universitas Singaperbangsa Karawang, 2021.

[12] I. Adhiwena, Pengukuran dan analisa distribusi temperatur pada ice bank untuk optimasi pengembangan mini ice plant, Skripsi, Universitas Indonesia, Depok,
2008.

[13] M. Hasan, Y. Haseli, and E. Karadogan, Correlations to predict elemental compositions and heating value of torrefied biomass, Energies, vol. 11, no. 9, 2018, pp. 115, DOI: 10.3390/en11092243.

[14] A. Özyuguran and S. Yaman, Prediction of calorific value of biomass from proximate analysis, Energy Procedia, vol. 107, 2017, pp. 130-136. DOI: 10.1016/j.egypro.2016.12.149. 